\title{
Outbreak of multidrug resistant Salmonella Typhimurium in calves at a veterinary hospital in Brazil
}

\author{
Carolina Pantuzza $\operatorname{Ramos}^{1}$ (iD) Letícia Camêlo Vespasiano ${ }^{1}$ (iD) Isabela Oliveira Melo ${ }^{1}$ (iD) \\ Rafael Gariglio Clark Xavier ${ }^{1}$ (D) Carlos Augusto Gomes Leal ${ }^{1}$ iD Elias Jorge Facury Filho ${ }^{1}$ iD \\ Antônio Ultimo de Carvalho ${ }^{1}$ iD Francisco Carlos Faria Lobato ${ }^{1}$ iD Rodrigo Otávio Silveira Silva ${ }^{*}$ (iD
}

${ }^{1}$ Universidade Federal de Minas Gerais (UFMG), Escola de Veterinária, 31270-901, Belo Horizonte, MG, Brazil. E-mail: rodrigo.otaviosilva@gmail.com. *Corresponding author.

ABSTRACT: The present study aimed to describe and characterize a nosocomial outbreak caused by a multidrug resistant Salmonella Typhimurium in hospitalized calves at a veterinary medical teaching hospital from Brazil. Sixty-three (96.9\%) calves showed lethargy, hyperthermia and profuse diarrhea and despite treatment, 26 (41.2\%) animals died. Five animals were necropsied and stool samples of six calves were collected. The isolated strains were subjected to antimicrobial susceptibility test by disc-difusion method and were fingerprinted by ERIC-PCR. Macroscopic lesions suggestive of salmonellosis, such as fibrinonecrotic enteritis and hepatosplenomegaly were observed. Salmonellosis was confirmed by isolation of S. Typhimurium from stool samples and organs from seven affected animals. Six out of seven isolates of S. Typhimurium, exhibited 100\% of similarity at ERIC-PCR, suggesting occurrence of nosocomial transmission of S. Typhimurium among the hospitalized calves. All but one S. Typhimurium isolated were resistant to marbofloxacin, enrofloxacin, florfenicol, oxytetracycline and trimethoprim/sulfamethoxazole, antimicrobial agents largely used for humans and animal treatment. This is the first study of a nosocomial outbreak of multidrug resistant $S$. Typhimurium in a veterinary hospital in Brazil and highlighted the need for preventive measures to reduce the risks for inpatients and humans in contact with animals.

Key words: salmonellosis, bovine, nosocomial, zoonosis, multiresistant.

Surto de Salmonella Typhimurium multirresistante em bezerros em um hospital veterinário do Brasil

RESUMO: O objetivo do presente estudo é descrever e caracterizar um surto nosocomial provocado por S. Typhimurium multirresistente em bezerros hospitalizados em um hospital escola de medicina veteriária localizado no Brasil. Sessenta e três (96,9\%) bezerros apresentaram letargia, hipertermia e diarreia profusa e, apesar do tratamento, vinte e seis animais (41,2\%) morreram. Cinco animais foram necropsiados e amostras fecais de seis bezerros foram coletadas. As estirpes isoladas foram submetidas a testes de susceptibilidade a antimicrobianos pelo método de disco-difusão e foram genotipadas pelo ERIC-PCR. Lesões macroscópicas sugestivas de salmonelose, como enterite fibrinonecrótica e hepatoesplenomegalia, foram observadas. Salmonelose foi confirmada pelo isolamento de S. Typhimurium em amostras fecais e órgãos de sete animais. Dos sete isolados, seis apresentaram 100\% de similaridade ao ERIC-PCR, sugerindo ocorrẽncia de transmissão nosocomial de S. Typhimurium entre os bezerros hospitalizados. Com excessão de uma estirpe, todas foram resistentes a marbofloxacina, enrofloxacina, florfenicol, oxitetraciclina e trimetoprima/sulfametoxazol, agentes antimicrobianos amplamente utilizados para o tratamento humano e animal. Esse é o primeiro estudo que demonstra um surto nosocomial de estirpes de S. Typhimurium resistentes a múltiplas drogas em um hospital veterinário no Brasil, enfatizando a necessidade de medidas preventivas que reduzam os riscos aos animais hospitalizados e a pessoas que entrarem em contato com esses animais.

Palavras-chave: salmonelose, bovinos, nosocomial, zoonose, multirresistente.

\section{INTRODUCTION}

Salmonellosis is a zoonotic disease of worldwide distribution and responsible for great economic losses in animal production (SANCHEZ et al., 2002), being also reported as a nosocomial pathogen at veterinary hospitals (CUMMINGS et al., 2010; HOLSCHBACH, PEEK, 2017). Among the several Salmonella enterica serovars associated with salmonellosis in cattle, $S$. Typhimurium stands out for its broad host range and its zoonotic transmission (MOHLER et al., 2009). In calves, it is commonly associated with enteric disease, which less frequently, could spread to other organs depending on the strain' virulence factors and the host immunity (MOHLER et al., 2009; HOLSCHBACH, PEEK, 2017).

Outbreaks of salmonellosis in hospitalized animals are frequently associated with nosocomial 
transmission (CUMMINGS et al., 2010). It is known that some animals can shed S. Typhimurium intermittently for a variable period, even in the absence of clinical signs (HOLSCHBACH, PEEK, 2017). This fecal shedding can increase during hospitalization due to the presence of some risk factors, including antimicrobial therapy (CUMMINGS et al., 2009). In addition, Salmonella spp. can easily disseminate in the hospital environment, infecting other susceptible individuals and then eventually leading to nosocomial outbreaks (BURGESS et al., 2004; DUNOWSKA et al., 2007; CUMMINGS et al., 2010). There are few studies on Salmonella infections in hospitalized calves and, so far, all reports are restricted to American and Canadian veterinary hospitals (IKEDA et al., 1986; RAVARY et al., 1998; CUMMINGS et al., 2009; CUMMINGS et al., 2010). The present study aimed to describe and characterize, for the first time, a nosocomial outbreak of multidrug resistant isolates of $S$. Typhimurium in hospitalized calves at a veterinary medical teaching hospital in Brazil. The isolated strains were evaluated for antimicrobial susceptibility by disc-difusion method and were fingerprinted by ERIC-PCR.

\section{MATERIALS AND METHODS}

\section{The outbreak}

From November 2016 to January 2017, 65 calves with 1-to-3 days old were admitted to the Veterinary Hospital of the Universidade Federal de Minas Gerais. These animals were all acquired from the same dairy farm located in metropolitan area of Belo Horizonte (Minas Gerais - Brazil) and would be raised until 30 days old when then would be part of a clinical experiment with Anaplasma marginale infection. Confined in a cattle shed, the animals were fed with hay, concentrate and milk replacer and would be daily examined until the clinical experiment.

The first group of calves $(n=18)$ arrived in November 2016. Three to four days after admission, the animals exhibited lethargy, hyperthermia and profuse diarrhea. These animals received oral fluid therapy and antimicrobial therapy with florfenicol, followed by ceftiofur, penicillin, marbofloxacin or trimethoprim/sulfamethoxazole. Despite the treatment, four animals $(22.2 \%)$ died. Similar to this first group, calves that arrived in December 2016 $(n=26)$ and January $2017(n=21)$ developed lethargy, hyperthermia and profuse diarrhea three to four days after admission. The same protocol of treatment was prescribed but, once no improvement of their clinical status was seen, antimicrobial therapy was changed to enrofloxacin. Eleven animals died in the months of December (42.3\%) and also in January $(52.3 \%)$. During the outbreak, a total of $63(96.9 \%)$ animals were clinically affected, of which $26(41.2 \%)$ died despite the treatment.

Calves that died during the outbreak were submitted to post mortem examination. Fragments of the liver, spleen, lungs and mesenteric lymph nodes from five animals were collected for histopathological analysis and bacterial culture. Biliary and intestinal contents were also collected from these animals. In addition, stool samples from other live animals were collected from six calves during the outbreak. All samples were stored at $4{ }^{\circ} \mathrm{C}$ until processing in the Bacteriology and Research Laboratory at the School of Veterinary, Universidade Federal de Minas Gerais.

\section{Isolation and characterization of Salmonella spp.}

Specimens collected during post mortem examination were submitted to isolation of Salmonella spp. as previously described (RAMOS et al., 2018). Identification of Salmonella genus were performed by PCR (KWANG et al., 1996) and Salmonella species and subspecies were identified according to LE MINOR \& POPPOFF (1987). The identification of the specific serovar was performed according to antigenic characterization reported by GRIMONT \& WEILL (2007) at the Brazilian National Reference Laboratory of Enterobacteriaceae of Oswaldo Cruz Foundation (FIOCRUZ), Brazilian Ministry of Health. In addition, stool samples and intestinal content were tested for the most common pathogens in neonatal calves (HELLER \& CHIGERWE, 2018) with previously described methods, including isolation and genotyping of Clostridium perfringens (DINIZ et al., 2018) and detection of rotavirus and coronavirus by RT-PCR (ASANO et al., 2010). Flotation method with Sheather's sugar solution followed by light microscopy was also used for routine parasitological detection. Additionally, detection of diarrheagenic Escherichia coli was performed according to FRANCK et al (1998) based on identification of virulence genes of ETEC ( $f 41$, k99, sta), EPEC (eae) and EHEC/STEC (stx 1, stx2).

The isolated strains were subjected to the antimicrobial susceptibility test by disc diffusion method according to Clinical and Laboratory Standards Institute (CLSI) manual VET01-A4 (CLSI, 2013). The following antimicrobials were tested: oxytetracycline $(30 \mu \mathrm{g})$, marbofloxacin $(5 \mu \mathrm{g})$, florfenicol $(30 \mu \mathrm{g})$, amoxicillin/clavulanic acid $(30 \mu \mathrm{g})$, trimethoprim/sulfamethoxazole $(25 \mu \mathrm{g})$, ceftriaxone $(30 \mu \mathrm{g})$ and enrofloxacin $(5 \mu \mathrm{g})$ (DME, Brazil). Additionally, to evaluate the genetic similarity 
between the isolates from the hospitalized calves, the strains were fingerprinted by ERIC-PCR using the primers ERIC-1 and ERIC-2 as previously described (VERSALOVIC et al., 1991). Amplified products of intergenic repetitive DNA sequences, which are imperfect palindromes reported in the genome of Salmonella Typhimurium isolates and commonly used as the basis for fingerprinting (WILSON \& SHARP, 2006) were submitted to gel electrophoresis and analyzed using the software Bionumerics 7.6 (Applied Maths, Belgium). Clustering analysis was based on the Dice similarity coefficient and the unweighted pair group method with arithmetic mean (UPGMA) algorithms (DORNELES et al., 2014).

\section{RESULTS AND DISCUSSION}

All necropsied animals showed the same pattern of macroscopic lesions suggestive for salmonellosis, such as fibrinonecrotic enteritis (Figure 1B), oedematous mesenteric lymph nodes and hepatosplenomegaly. Some calves have shown additional macroscopic finds such as congested meninges and pneumonia (Figure 1A).

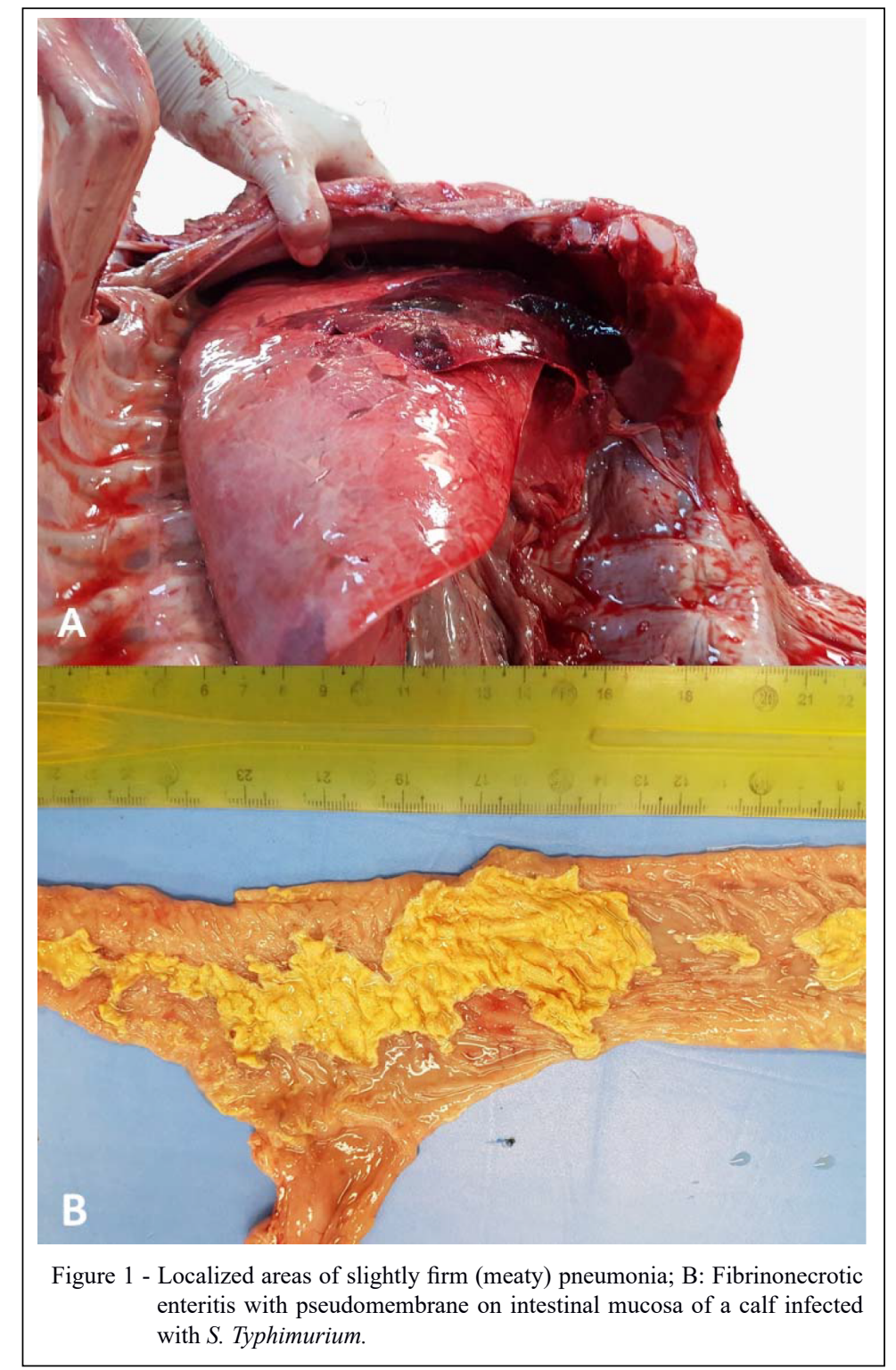

Ciência Rural, v.49, n.2, 2019. 
Clinical signs and post mortem alterations seen during the outbreak are commonly described in salmonellosis in cattle (HOLSCHBACH, PEEK, 2017). Despite that, laboratorial diagnostic is still need to confirm the diagnosis of infection by Salmonella spp. and also to evaluate the possible association with other enteropathogens (BLANCHARD, 2012). Salmonella Typhimurium was recovered from the intestinal content, spleen, liver and mesenteric lymph nodes from all five necropsied calves, additionally from the lungs of one calf. This serovar was also isolated from two out of six tested stool samples from live calves, thus reinforcing the hypothesis of nosocomial transmission (Table 1).

The laboratory diagnosis also ruled out the presence of other common enteropathogens of young calves, including enterotoxigenic E. coli, rotavirus and C. perfringens type C (HELLER, CHIGERWE, 2018). E. coli was isolated in fecal material from all tested animals, but no virulence factor was detected in these strains. C. perfringens type A, which is commonly part of the intestinal microbiota of calves, was recovered from the stool samples of all sampled animals. C. perfringens type $\mathrm{C}$, which is associated with necrotic enteritis in neonatal calves (UZAL et al., 2015), were not detected in the present report.

To better understand the transmission patterns during the outbreak, one S. Typhimurium isolate from each animal $(\mathrm{n}=7)$ (Figure 2) were fingerprinted by ERIC-PCR (VERSALOVIC et al., 1991). This molecular tool have been shown to efficiently fingerprinted Salmonella strains in outbreak investigations with a high discriminatory power (AMMARI et al., 2009; SMITH et al., 2011; HASHEMI \& BAGHBANI-ARANI, 2015;
PURIGHALLA et al., 2017). In the present report, the majority of the isolates showed an identical pattern in the ERIC-PCR (Figure 2), suggesting all emerged from the same clone. The only exception was the first isolate obtained during the outbreak, which was recovered from a calve in November 2016. Anyway, using $90 \%$ similarity as a cutoff point (HASHEMI \& BAGHBANI-ARANI, 2015; RAMOS et al., 2018), this isolate also showed a high similarity with all other isolates, suggesting a closely relationship among all sampled strains in the outbreak and confirming the hypothesis of nosocomial transmission among the hospitalized calves.

S. Typhimurium is one of the most common Salmonella serovars responsible for infection in animals worldwide, being also known as an important zoonotic agent (HOLSCHBACH, PEEK, 2017). This serovar was also previously described as most common associated with nosocomial outbreaks at large-animal veterinary hospitals (RAVARY et al., 1998; WARD et al., 2005, CUMMINGS et al., 2010, LEON et al., 2018). In fact, it is known that cattle kept in a hospital settings are at risk of salmonellosis due to the presence of several predisposing factors, such as affected gut microbiota by antimicrobial and proton bomb inhibitors administration, concurrent diseases and status of immunossuppression (EWART et al., 2001; CUMMINGS et al., 2009). Additionally to these risk factors, previous reports have also shown a higher fecal shedding of Salmonella spp among hospitalized and dairy cattle in the summer and fall (PANGLOLI et al., 2008; CUMMINGS et al., 2009). Interestingly, the outbreak of Salmonella Typhimurium described in the present study occurred during the summer months in Brazil, corroborating with previous researches.

Table 1 - Source and period of isolation and antimicrobial resistance of Salmonella Typhimurium from hospitalized calves.

\begin{tabular}{lccc}
\hline Strain & & & \\
& Source & Resistance profile \\
\hline B7 & Liver & Month/year & \\
B38 & Feces & November/2016 & $1,2,3,5,7$ \\
B47 & Lungs & December/2016 & $1,2,3,5,7$ \\
B57 & Spleen & January/2017 & $1,2,3,5,7$ \\
B58 & Intestinal content & January/2017 & $1,2,3,5,7$ \\
B59 & Feces & January/2017 & $1,2,3,5,7$ \\
B60 & Mesenteric lymph nodes & January/2017 & Susceptible to all \\
\hline
\end{tabular}

*1: Oxytetracycline; 2: Marbofloxacin; 3: Florfenicol; 4: Amoxicillin/clavulanic acid; 5: Trimethoprim/sulfamethoxazole; 6 : Ceftriaxone; 7: Enrofloxacin. 


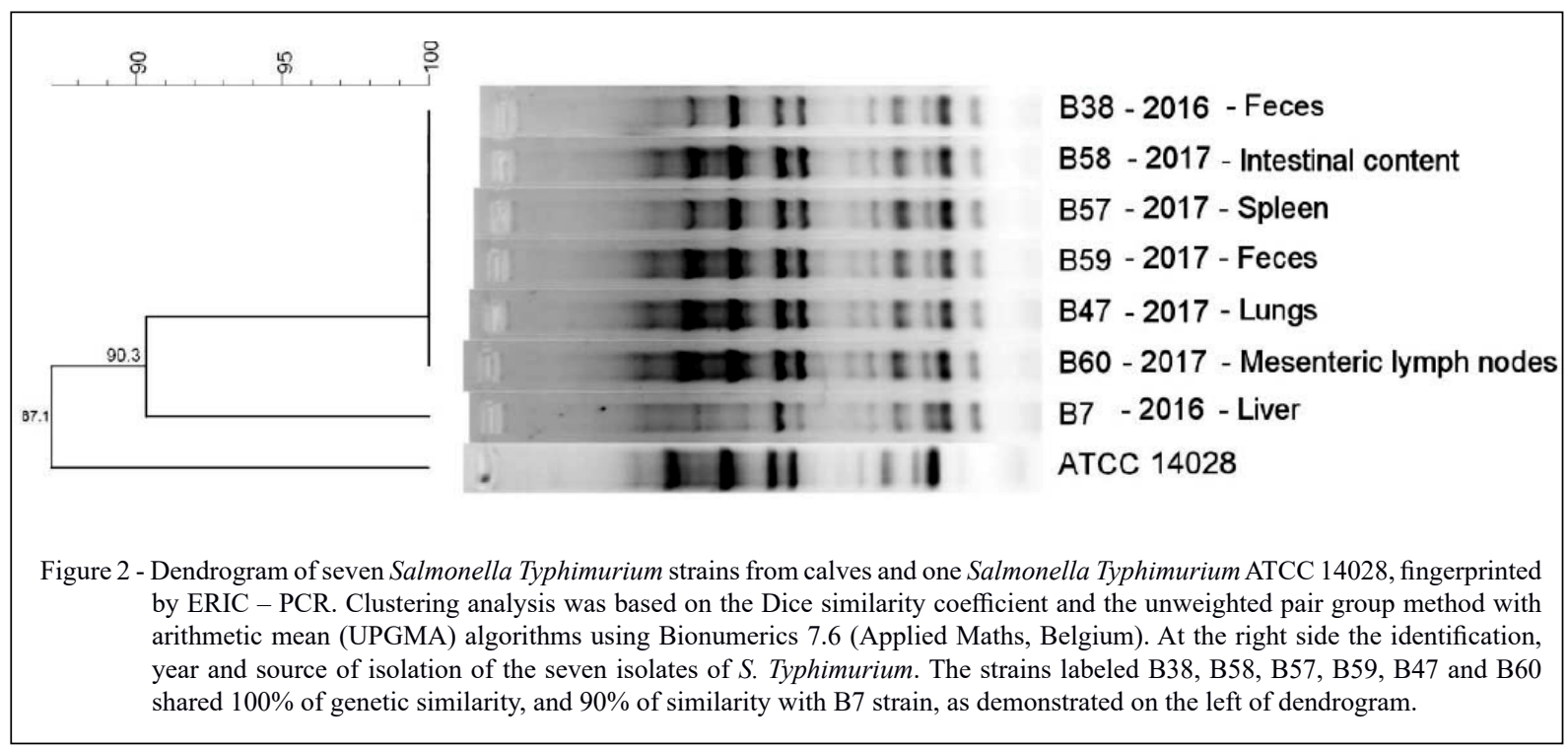

Seven clinical isolates of S. Typhimurium from calves were also subjected to the antimicrobial susceptibility test by disc diffusion method (CLSI, 2013). Antimicrobials commonly used in animals, including for treatment of salmonellosis in humans and animals, were selected (HOHMANN, 2001; PARVATHI et al., 2011; CLSI, 2015; OIE, 2015). All Salmonella isolates were susceptible to amoxicillin/ clavulanic acid and ceftriaxone. Of the seven sampled animals, just one Salmonella strain from a calf was susceptible to all antimicrobial agents tested, including the drugs used for their treatment (florfenicol, trimethoprim/sulfamethoxazole and enrofloxacin), contrasting with results of other isolates. It is important to note that this infected calf did not die, demonstrating, in addition to other factors, their clinical improvement due to response for the antimicrobial administration. Conversely, another animal, treated with ceftiofur, trimethoprim/ sulfamethoxazole and enrofloxacin also survived to the infection; although, the resistance of their Salmonella isolates to trimethoprim/sulfamethoxazole and enrofloxacin. Clinical improvement could be attributed, among other factors, to the administration of ceftiofur, a third-generation cephalosporin recommended for salmonellosis treatment in animals (OIE, 2015).

Multidrug-resistant strains of zoonotic Salmonella spp. are commonly associated with outbreaks in calves (MOHLER et al., 2009; HOLSCHBACH, PEEK, 2017). In fact, isolates in the present study were simultaneously resistant to more than three classes of antimicrobials, corresponding to marbofloxacin, enrofloxacin, florfenicol, oxytetracycline and trimethoprim/sulfamethoxazole. It is widely known that dissemination of antimicrobial resistance among Salmonella serovars has become a public health concern (WHO, 2017; PARISI et al., 2018). As described, six out of seven tested isolates were resistant to marbofloxacin and enrofloxacin, agents considered critically important for treating human and animals (OIE, 2015, WHO, 2017). Additionally, Salmonella fluoroquinolone-resistant is one of 12 bacteria for which new antibiotics are urgently needed, according to World Health Organization (WHO, 2017). It is also important to note that only one calf from which this isolates were recovered was previously treated with enrofloxacin and none had direct contact with marbofloxacin. Interestingly, both antimicrobial agents were used for treatment of others calves, of which could justify the emergence and spread of resistance for these drugs (ALLEN et al., 2010). Salmonella isolates from these six calves were also resistant to florfenicol, oxytetracycline and trimethoprim/sulfamethoxazole, antimicrobial agents commonly used in veterinary medicine as well as for treatment of diarrhea in calves (PEZZELLA et al., 2004; KUANG et al., 2015). It is noteworthy that three sampled calves were treated with florfenicol while four received trimethoprim/ sulfamethoxazole. Although, none animal has been treated with oxytetracycline in the present report, 
the resistance could be explained by the widespread increasing of tetracycline resistance, mainly attributed to the largely and indiscriminate use of this class of antimicrobial agent (CHOPRA \& ROBERTS, 2001; SHIN et al., 2015).

Salmonella spp. isolates from outbreaks are commonly phenotypically similar, with shared antimicrobial susceptibility patterns and serotypes (BURGESS \& MORLEY, 2014). In the present work, most isolates shared the same serotypes, antimicrobial resistance profile as well as genotypic patterns at ERIC-PCR, confirming its nosocomial transmission (BURGESS, MORLEY, 2014; CUMMINGS et al., 2014).

To reduce the consequences associated with Salmonella spp. into hospital settings, including the emergence of antimicrobial resistance and zoonotic transmission, active surveillance of this agent in patients and environments is necessary to identify and control the outbreaks early in their course. Control measures such as isolation of symptomatic calves and asymptomatic shedders, disinfection of shared equipment between patients and cleaning and disinfection of floors at least twice daily should be taken to reduce both nosocomial and zoonotic transmission of salmonellosis (STENERODEN et al., 2010).

\section{CONCLUSION}

This is the first description of a nosocomial outbreak of multidrug resistant Salmonella Typhimurium in a veterinary hospital in Brazil. The present research highlighted the need for preventive measures to reduce the risks for inpatients and humans in contact with animals.

\section{ACKNOWLEDGMENTS}

This study was supported by Coordenação de Aperfeiçoamento de Pessoal de Nível Superior (CAPES), Conselho Nacional de Desenvolvimento Científico e Tecnológico $(\mathrm{CNPq})$, Fundação de Amparo à Pesquisa do Estado de Minas Gerais (FAPEMIG) and Pró Reitoria de Pesquisa da Universidade Federal de Minas Gerais (PRPq/UFMG). Francisco Carlos Faria Lobato have a research fellowship from Conselho Nacional de Desenvolvimento Científico e Tecnológico (CNPq).

\section{BIOETHICS AND BIOSSECURITY COMMITTEE APPROVAL}

We authors of the article entitled "Outbreak of multidrug resistant Salmonella Typhimurium in calves at a veterinary hospital in Brazil" declared, for all due purposes, the project that gave rise to the present data has not been submitted for evaluation to the Ethics Committee of the Federal University of Minas Gerais, but we are aware of the content of the Brazilian resolutions of the National Council for Control of Animal Experimentation - CONCEA "http://www.mct.gov.br/index.php/ content/view/310553.html" if it involves animals. Thus, the authors assume full responsibility for the presented data and are available for possible questions, if they be required by the competent authorities.

\section{DECLARATION OF CONFLICTING INTERESTS}

The authors declare no conflict of interest. The founding sponsors had no role in the design of the study; in the collection, analyses, or interpretation of data; in the writing of the manuscript, and in the decision to publish the results.

\section{AUTHORS' CONTRIBUTIONS}

All authors contributed equally for the conception and writing of the manuscript. All authors critically revised the manuscript and approved of the final version.

\section{REFERENCES}

ALLEN, H. K. et al. Call of the wild: Antibiotic resistance genes in natural environments. Nature Rev Microbiol, v.8, p.251-259, 2010. Available from: <https://www.nature.com/articles/nrmicro2312>. Accessed: Sep. 23, 2018. doi: 10.1038/nrmicro2312.

AMMARI, S. et al. Characterization of Salmonella Enteritidis isolated from foods and patients in northern Morocco. J Infec Devel Ctries, v. 3, p.695-703, 2009. Available from: $<$ https://www. ncbi.nlm.nih.gov/pubmed/19858571>. Accessed: Sep. 24, 2018.

ASANO, K. M. et al. Multiplex semi-nested RT-PCR with exogenous internal control for simultaneous detection of bovine coronavirus and group A rotavirus. J Virol Methods, v.169, n.2, p.375-379, 2010. Available from: <http://dx.doi.org/10.1016/j. jviromet.2010.08.008>. Accessed: Sep. 24, 2018.

BLANCHARD, P. C. Diagnostics of dairy and beef cattle diarrhea. Vet Clin North Am Food Anim Pract, v.28, n.3, p.443-464, 2012. Available from: <https://www.ncbi.nlm.nih.gov/ pubmed/23101670>. Accessed: Sep. 23, 2018. doi: 10.1016/j. cvfa.2012.07.002.

BURGESS, B. A. et al. Environmental surveillance for Salmonella enterica in a veterinary teaching hospital. J Am Vet Med Assoc, v.225, n.9, p.1344-1348, 2004. Available from: $<$ https://www.ncbi. nlm.nih.gov/pubmed/15552306>. Accessed: Sep. 23, 2018.

BURGESS, B. A.; MORLEY, P. S. Managing salmonella in equine populations. Vet Clin North Am: Equine Pract, v.30, n.3, p.623-640, 2014. Available from: $<$ https://www.ncbi.nlm.nih.gov/ pubmed/25282320>. Accessed: Sep. 23, 2018. doi: 10.1016/j. cveq.2014.08.005.

CHOPRA. I.; ROBERTS, M. Tetracycline antibiotics: mode of action, applications, molecular biology, and epidemiology of bacterial resistance. Microbiol Mol Biol Rev, v.65, p.232-260, 2001. Available from: <https://www.ncbi.nlm.nih.gov/pubmed/11381101>. Accessed: Sep. 24, 2018. doi: 10.1128/MMBR.65.2.232-260.2001.

CUMMINGS, K. J. et al. Fecal shedding of Salmonella spp among cattle admitted to a veterinary medical teaching hospital. J Am 
Vet Med Assoc, v.234, n.12, p.1578-1585, 2009. Available from: $<$ https://www.ncbi.nlm.nih.gov/pubmed/19527134>. Accessed: Sep. 24, 2018. doi: 10.2460/javma.234.12.1578.

CUMMINGS, K. J., et al. Temporal clusters of bovine Salmonella cases at a veterinary medical teaching hospital, 1996-2007. Vector Borne Zoonotic Dis., v.10, p.471-479, 2010. Available from: $<$ https://www.ncbi.nlm.nih.gov/pubmed/19877812>. Accessed: Sep. 24, 2018. doi: 10.1089/vbz.2009.0068.

CUMMINGS, K. J. et al. Salmonella enterica serovar Oranienburg outbreak in a veterinary medical teaching hospital with evidence of nosocomial and on-farm transmission. Vector Borne Zoonotic Dis, v.14, n.7, p.496-502, 2014. Available from: <https://www. ncbi.nlm.nih.gov/pubmed/24902121>. Accessed: Sep. 24, 2018. doi: $10.1089 / \mathrm{vbz} .2013 .1467$.

CLINICAL AND LABORATORY STANDARDS INSTITUTE [CLSI]. Performance standards for antimicrobial susceptibility testing. M100-S25, Twenty-Fifth Informational Supplemen. Pennsylvania, v.35, n.3, 240p, 2015.

CLINICAL AND LABORATORY STANDARDS INSTITUTE [CLSI]. Performance standards for antimicrobial disk and dilution susceptibility tests for bacteria isolated from animals. VET01-A4, Approved Standard-Fourth Edition. Pennsylvania, v33, n.7, 94p, 2013.

DINIZ, A. N. et al. The incidence of Clostridioides difficile and Clostridium perfringens netF-positive strains in diarrheic dogs. Anaerobe, v.49, p.58-62, 2018. Available from: <https://www. ncbi.nlm.nih.gov/pubmed/29274467>. Accessed: Sep. 24, 2018. doi: 10.1016/j.anaerobe.2017.12.003.

DORNELES, E. M. S. et al. Evaluation of ERIC-PCR as Genotyping Method for Corynebacterium pseudotuberculosis Isolates. PLOS ONE, p.9, n.6. e98758, 2014. Available from: $<$ https://journals.plos.org/plosone/article?id=10.1371/journal. pone.0098758>. Accessed: Dec. 23, 2018. doi: 10.1371/journal. pone. 0098758

DUNOWSKA, M. et al. Comparison of Salmonella enterica serotype Infantis isolates from a veterinary teaching hospital. J Appl Microbiol, v.102, p.1527-1536, 2007. Available from: $<$ https://www.ncbi.nlm.nih.gov/pubmed/17578417>. Accessed: Sep. 23, 2018. doi: 10.1111/j.1365-2672.2006.03198.x.

EWART, S. L. et al., Identification of sources of Salmonella organisms in a veterinary teaching hospital and evaluation of the effects of disinfectants on detection of Salmonella organisms on surface materials. J Am Vet Med Assoc, v.218. n.7, p.114551, 2001. Available from: <https://www.ncbi.nlm.nih.gov/ pubmed/11318367>. Accessed: Sep. 23, 2018.

FRANCK, S. M. et al. Multiplex PCR for enterotoxigenic, attaching and effacing, and Shiga toxin-producing Escherichia coli strains from calves. Journal of Clinical Microbiology, v.36, n.6, p.1795-7, 1998. Available from: <https:/www.ncbi.nlm.nih.gov/ pubmed/9620426>. Accessed: Sep. 24, 2018.

GRIMONT, P. A. D.; WEILL, F. X. Antigenic Formulas of the Salmonella Serovar. Paris: Institut Pasteur, 2007. 167 p. $9^{\text {th }}$.

HASHEMI, A.; BAGHBANI-ARANI, F. The effective differentiation of Salmonella isolates using four PCR-based typing methods. J Appl Microbiol, v.118, n.6, p.1530-1540, 2015. Available from: <https://www.ncbi.nlm.nih.gov/pubmed/25809397>. Accessed: Dec. 23, 2018. doi: 10.1111/jam. 12805 .

HELLER, M. C.; CHIGERWE M. Diagnosis and Treatment of Infectious Enteritis in Neonatal and Juvenile Ruminants. Vet Clin North Am: Food Anim Pract, v.34, n.1, p.101-117, 2018. Available from: $<$ https://www.ncbi.nlm.nih.gov/pubmed/29275032>. Accessed: Sep. 24, 2018. doi: 10.1016/j.cvfa.2017.08.001.

HOHMANN, E. L. Nontyphoidal salmonellosis. Clin Infect Dis, v.32, n.2, p.263-269, 2001. Available from: <https://www.ncbi. nlm.nih.gov/pubmed/11170916>. Accessed: Sep. 24, 2018. doi: $10.1086 / 318457$.

HOLSCHBACH, C. L.; PEEK, S. F. Salmonella in Dairy Cattle. Vet Clin North Am Food Anim Pract., v.34, n.1, p.133-154, 2017. Available from: <https://www.vetfood.theclinics.com/ article/S0749-0720(17)30085-3/fulltext $>$. Accessed: Sep. 24, 2018. doi: 10.1016/j.cvfa.2017.10.005.

IKEDA, J. S. et al. Characteristics of Salmonella isolated from animals at a veterinary medical teaching hospital. Am J Vet Res, v.47, p.232-235, 1986. Available from: <https://www.ncbi.nlm. nih.gov/pubmed/3954196>. Accessed: Sep. 24, 2018.

KUANG, X. et al. Yuan, Zonghui. Serotypes and antimicrobial susceptibility of Salmonella spp. isolated from farm animals in China. Front. Microbiol., v.6, p.602, 2015. Available from: $<$ https://www.ncbi.nlm.nih.gov/pmc/articles/PMC4476277/>. Accessed: Sep. 24, 2018. doi: 10.3389/fmicb.2015.00602.

KWANG, J. et al. Use of the polymerase chain reaction for Salmonella detection. Lett Appl Microbiol, v.22, p.4651, 1996. Available from: <https://www.ncbi.nlm.nih.gov/ pubmed/8588887>. Accessed: Sep. 24, 2018. doi: 10.1111/j.1472765X.1996.tb01106.x.

LE MINOR, L.; POPPOFF, M. Y. Designation of Salmonella enterico sp. nov. as the type and only species of the genus Salmonella. Int J Syst Evol Microbiol. v.37, p.465-468, 1987. Available from: <http://ijs.microbiologyresearch.org/content/ journal/ijsem/10.1099/00207713-37-4-465>. Accessed: Sep. 24 2018. doi: 10.1099/00207713-37-4-465.

LEON, I. M. et al. Serotype diversity and antimicrobial resistance among Salmonella enterica Isolates from Patients at an Equine Referral Hospital. Applied and environmental microbiology, v.84, n.13, 2018. Available from: <https://www.ncbi.nlm.nih. gov/pubmed/29678910>. Accessed: Dec. 23, 2018. doi: 10.1128/ AEM.02829-17.

MOHLER, V. L. et al. Salmonella in calves. Vet Clin North Am Food Anim Pract., v.25, n.1, p.37-54, 2009. Available from: $<$ https://www.ncbi.nlm.nih.gov/pubmed/19174282>. Accessed: Sep. 24, 2018. doi: 10.1016/j.cvfa.2008.10.009.

PANGLOLI, P. et al. Seasonal incidence and molecular characterization of Salmonella from dairy cows, calves, and farm environment. Foodborne Pathog Dis, v.5, p.87-96, 2008. Available from: $<$ https://www.ncbi.nlm.nih.gov/pubmed/18260819 $>$. Accessed: Dec. 23, 2018. doi: 10.1089/fpd.2008.0048.

PARISI, A. et al. Health Outcomes from Multidrug-Resistant Salmonella Infections in High-Income Countries: A Systematic Review and Meta-Analysis. Foodborne Pathogens and Disease, v.15, n.7, p.428-436, 2018. Available from: <https://www.ncbi. 
nlm.nih.gov/pubmed/29624414>. Accessed: Sep. 24, 2018. doi: $10.1089 /$ fpd.2017.2403.

PARVATHI A. et al. Comparative virulence genotyping and antimicrobial susceptibility profiling of environmental and clinical Salmonella enterica from Cochin, India. Curr Microbiol., v.62, n1, p.21-26, 2011. Available from: <https://www.ncbi.nlm.nih.gov/pubmed/20490498>. Accessed: Sep. 24, 2018. doi: 10.1007/s00284-010-9665-7.

PEZZELLA, C. A. et al. Tetracycline and streptomycin resistance genes, transposons, and plasmids in Salmonella enterica isolates from animals in Italy. Antimicrob. Agents Chemother. v.48, p.903-908, 2004. Available from: <https://www.ncbi.nlm.nih.gov/pubmed/14982782>. Accessed: Sep. 23, 2018. doi: 10.1128/AAC.48.3.903-908.2004.

PURIGHALLA, S. et al. Investigation into a community outbreak of Salmonella Typhi in Bengaluru, India. The Indian Journal of Medical Research, v.146, p.15-22, 2017. Available from: <https:// www.ncbi.nlm.nih.gov/pubmed/29205191>. Accessed: Sep. 24, 2018. doi: 10.4103/ijmr.IJMR_1201_16.

RAMOS, C. P. et al. Antimicrobial susceptibility and molecular characterization of Salmonella serovar Ndolo isolated from outbreaks in cattle and horses. Cienc. Rural, v.48, n.12, 2018. Available from: $<$ http://www.scielo.br/scielo.php?script $=$ sci_arttext\&pid=S010384782018001200452\&lng=en\&nrm=iso $>$. Accessed: Dec. 23, 2018. doi: $10.1590 / 0103-8478 \mathrm{cr} 20180688$.

RAVARY, B. et al. Prevalence of infections caused by Salmonella spp. in cattle and horses at the Veterinary Teaching Hospital of the Faculty of Veterinary Medicine of the University of Montreal. Can Vet J, v.39, p.566-572, 1998. Available from: <https://www.ncbi. nlm.nih.gov/pubmed/9752593>. Accessed: Sep. 24, 2018.

SANCHEZ, S. et al. Animal sources of salmonellosis in humans. JAVMA, v.221, p.492-497, 2002. Available from: <https://www. ncbi.nlm.nih.gov/pubmed/12184697>. Accessed: Sep. 24, 2018. doi: 10.2460/javma.2002.221.49.

SHIN, S. W. et al. Prevalence of antimicrobial resistance and transfer of tetracycline resistance genes in Escherichia coli isolates from beef cattle. Appl Environ Microbiol, v.81, p.5560-5566, 2015. Available from: <https://www.ncbi.nlm.nih.gov/pubmed/26048929>. Accessed: Sep. 24, 2018. doi: 10.1128/AEM.01511-15.
SMITH, S. I. et al. Molecular typing of Salmonella spp isolated from food handlers and animals in Nigeria. IJMEG, v.2, n.1, p.73-77, 2011. Available from: <https:/www.ncbi.nlm.nih.gov/ pmc/articles/PMC3077241/>. Accessed: Sep. 23, 2018.

STENERODEN, K. K. et al. Detection and control of a nosocomial outbreak caused by Salmonella Newport at a large animal hospital. J Vet Intern Med, v.24, n.3, p.606-616, 2010. Available from: $<$ https://www.ncbi.nlm.nih.gov/pubmed/20337913>. Accessed: Sep. 22, 2018. doi: 10.1111/j.1939-1676.2010.0484.x.

UZAL, F. A. et al. Animal models to study the pathogenesis of human and animal Clostridium perfringens infections. Vet Microbiol. v.179: p.23-33, 2015. Available from: <https://www. ncbi.nlm.nih.gov/pubmed/25770894>. Accessed: Sep. 24, 2018. doi: 10.1016/j.vetmic.2015.02.013.

VERSALOVIC, J. et al. Distribution of repetitive DNA sequences in eubacteria and application to fingerprinting of bacterial genomes. Nucleic Acids Res, v.19, n.24, p.6823-6831, 1991. Available from: < https://www.ncbi.nlm.nih.gov/pmc/articles/PMC329316/>. Accessed: Dec. 22, 2018. PMID: 1762913.

WARD, M. P. et al. Investigation and control of an outbreak of salmonellosis caused by multidrug-resistant Salmonella Typhimurium in a population of hospitalized horses. Vet Microbiol, v.107, p.233-240, 2005. Available from: <https://www.ncbi. nlm.nih.gov/pubmed/15863282>. Accessed: Sep. 22, 2018. doi: 10.1016/j.vetmic.2005.01.019.

WILSON, L. A.; SHARP, P. M. Enterobacterial Repetitive Intergenic Consensus (ERIC) Sequences in Escherichia coli: Evolution and Implications for ERIC-PCR. Mol Biol Evol., v.23, n.6, p.1156-1168, 2006. Available from: <https://www.ncbi. nlm.nih.gov/pubmed/16533821>. Accessed: Dec. 23, 2018. doi: 10.1093/molbev/msj125.

WORLD HEALTH ORGANIZATION [WHO]. Critically important antimicrobials for human medicine- 5th rev. Geneva: World Health Organization; 2017. 42p.

WORLD ORGANIZATION FOR ANIMAL HEALTH [OIE]. Oie List of Antimicrobial Agents of Veterinary Importance. Paris: OIE International Commitee, 2015. 9p. 